\title{
Responding To Globalization's Impact On Local Communities: Preparing For Global Tourism Expansion In Cuba
}

\author{
Manuel Ramón González Herrera \\ Institute of Social Sciences and Management. Tourism Program. Autonomous University of \\ Ciudad Juarez (UACJ), Mexico;
}

Jerry Spiegel

Liu Institute for Global Issues, University of British Columbia (UBC). Department of Health Care and Epidemiology, UBC. Institute of Health Promotion Research, UBC. Canada;

\begin{abstract}
This paper explores how the concept of resistance can be incorporated for understanding the effects of globalization on local communities in order to strengthen capacities for optimizing benefits and mitigating negative effects. The paper describes how the hierarchy of institutional, economic, social-cultural and ecological factors that can produce local impacts can accordingly serve as the basis for monitoring as well as for developing policy options in support of identified values and concerns, bringing together a range of disciplinary and stakeholder perspectives. Using a case study conducted in a Cuban coastal community potentially vulnerable to effects of global tourism expansion, the application of this approach is introduced as a way to link producers and users of relevant population information. In light of increased awareness of the impact of adverse potential effect of community restructuring associated with the global expansion of tourism merits attention. In the context of the potential population health implications of tourism expansion the challenge that emerges is not merely to better identify the risks and threats that constitute pathways that can lead to local health effects, but to consider options for mitigating negative impacts and taking advantage of positive opportunities. While Cuba is in many ways unique, the approach described above can provide valuable lessons to the international community in navigating a course between the allure of tourism dollars and the health and well-being of local populations.
\end{abstract}

Keywords: Globalization; Health; Tourism; Impacts; local communities, Cuba.

\section{INTRODUCTION}

Tourism has become one of the most important activities around the world; this growth means important challenges for local destinations [1], [2], [3]. Particularly, tourism income represents more than $30 \%$ of GDP for some countries in our region [4]. That is why, a critical turn in tourism studies has taken place [5], especially related to planning for Hospitality and Tourism [6] versus unplanned mass tourism [7]. All of these new focuses have been closely related to sustainable tourism and impact management in a context of innovation and associated with communities' participation [8], [9], [10], [11].

Concern over the effects of globalization on health and wellbeing has prompted an increased attention to explaining how distal "upstream" forces can produce health consequences through a range of intermediary factors [12]. While the frameworks developed for such purpose have helped to elucidate order amid complexity and suggest priority areas to consider, by 
themselves they nevertheless remain removed from the preparation of responses by those who are vulnerable to the identified effects [13], [14].

Through a research program initiative explicitly designed to examine the interactions of globalization, social organization and health, a team of Canadian, Cuban and Mexican researchers came together to develop a process to assist potentially affected communities build their response capacity to such pressures [15]. Acknowledging the pervasive reach of globalization itself, the pilot study for this program was selected to be undertaken in Cuba, a context frequently considered to be on the margins of globalization, but one where increased integration into the global economy presently underway through the expansion of tourism provided a distinct "natural experiment". This paper introduces and explains the conceptual framework that was developed to guide the research that the team is pursuing, so that it can be considered for application in other contexts as well.

\section{Globalization, social organization and health}

\section{LITERATURE REVIEW}

Over the past 40 years, global linkages in economic, technological and cultural domains have markedly expanded in the context of an increasingly dense web of international treaties, institutions and other relationships [16], [17], [18], [19], [20], [21] that have intensified worldwide interactions. While proponents of the benefits of globalization have emphasized the potential that exists for improving health as a consequence of increased trade and wealth creation building on the power of new technologies [22], critics have especially expressed concern over the creation of increased disparities and accompanying threats to health [23], [24].

In this context, the growing literature on how inequalities and diminished social capital within communities adversely affect population health [25], [26] has assumed special significance with regard to the potential impacts of globalization as an aggravating pressure, over and above consideration of other risk factors that can produce health effects. The establishment of the World Health Organization's Commission on Social Determinants of Health in 2005 [27], and its call for developing effective interventions and strategies, has served to draw even further attention to the significance of such forces.

\section{Conceptual frameworks and health impacts}

Efforts to better comprehend how intensified global interactions produce impacts have stimulated the development of various conceptual models. While economic globalization has been the subject of considerable attention to highlight the power distribution that influences the dynamics at play [28], [29], [21], attention has also been draw to the importance of giving full consideration to a broader range of pervasive globalizing cultural, economic and political factors conditioning impacts on local communities and their populations [30], [12], [31], [14], [32]. In light of this dynamic, globalization can thus itself be viewed as a key contextual determinant of more proximal health determinants [33].

As an understanding of the interplay of "macro" factors associated with "globalization" is gained, however, it remains imperative to not lose sight of the local contexts where impacts are experienced. Moreover, it is from the perspective of such effects that a consideration of health promoting policy response options should be considered at a multiplicity of levels - from local to national to global and back again. We can accordingly conceptualize a framework that 
incorporates the multi-dimensionality that has been suggested by Huynen et al., (2005), while incorporating the consideration of resistance presented by Spiegel and Andruske [34] to highlight a consideration of how responses to the range of potential impacts can be organized at different levels of social aggregation. Both of these models recognize the inherent global power inequities that [29], [28] closely associate with economic globalization, but explicitly identify the full range of dimensions through which effects are experienced.

While the conceptual model laid out by Huynen et al., [12] primarily seeks to explain how different bodies of knowledge relate to each other and should be considered, the analysis we wished to pursue sought to especially comprehend how the transmission of context-specific "driving forces" and associated "pressures" could trigger local impacts, and more importantly to consider the actions that can be pursued for responding to, if not anticipating and preventing negative impacts and health effects. In applying the vocabulary first suggested by cultural anthropologist [35] to identify the terrains, or "scapes" through which various influences are manifest (e.g. global financial, technological, demographic, cultural and ideological). While the concept of resistance in relation to the effects of globalization has primarily focused on the role of social movements, it is indeed a central concept to consider in the systematic pursuit of responses to specific pressures of globalization, by means of adaptation, protection or mitigation [36], [37], [20].

To further operationalize this analysis of globalization so that it could be applied and considered by stakeholders in specific settings, we decided to adapt a conceptual framework, the DPSEEA (Driving force - Pressure - State - Exposure - Effect - Action) model that had heretofore largely been restricted to consideration of environmental health impacts [38], [39], [14]. While appearing linear in its presentation, it allows for consideration of various feedback loops through the complexities of interactions as they are experienced, but above all creates a framework for considering points of intervention (actions) [40], [2]. The usefulness of these conceptual frameworks will be explained further in the case study described below, which provides a specific context for exploring their utility.

\section{METHODS}

This research describes a methodology (Figure 1), that is able to gather and process information related to key questions addressed in the pilot study: Can the links between tourism development and impacts be systematically identified by the community?; Are the tourism impacts different at different stages of tourism development?; Can comprehensive qualitative and quantitative indicators be identified that might tell the tale of the 'real' impact?; Can both men and women be adequately represented by the indicators?; Can mitigating policy measures for protecting and promoting development be identified?; Can the findings be applied to a wider global community?

Two communities in Cuba at different stages of tourism development have been chosen as the backdrop for the methodology: Cárdenas, an established tourism site and Caibarién, a new tourist development, both described below. For this pilot project, the main goal has been to gain broad knowledge about the relationships between globalization, tourism and impacts in the context of coastal communities. The outcome is a methodology for identifying how global forces affect social organization and wellbeing in communities, so that policy implications and options can be considered and comparative studies conducted to monitor vulnerabilities and the effectiveness of health-promoting policies. The main features of the methodology are community participation and rapid assessment of impacts for decision-makers. 
Figure 1. Structure of the proposed methodological process



LEARN COMMUNITY PERCEPTION ABOUT TOURISM AND IMPACTS

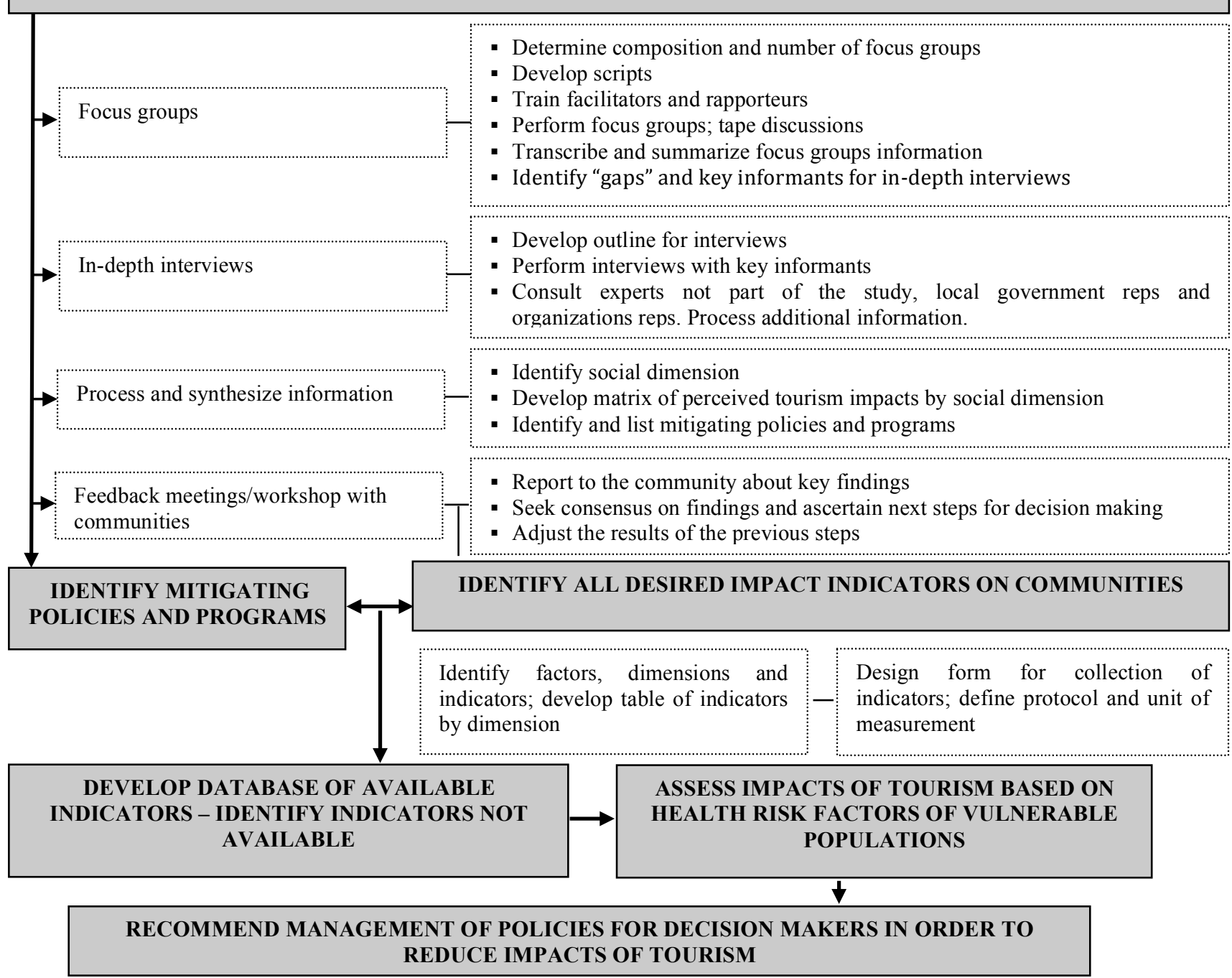

It has been selected the combination of team meetings, literature review, focus groups, key informant interviews, and review of secondary data (i.e. rapid assessment technique - rather than the conducting of household surveys or more extensive ethnographic study methods). 
The centerpiece of the methodology was a series of focus groups and key informant interviews to outline concerns, perceptions and observations related to tourism development.

\section{Presentation}

\section{CASE STUDY CONTEXT: BACKGROUND}

Restructuring in response to economic pressures is truly a global phenomenon - increasingly evident in both developed and developing countries. In high-income countries such as Canada, communities that had grown up around primary resource activities such as fishing and logging activity have seen their very survival jeopardized by declines in these sectors, while the aesthetic attributes of their locations have attracted the evolving tourism marketplace [41]. In poor and low-income countries hungry for foreign exchange, these trends have been even more evident - exacerbated by market pressures and opportunities emanating from the highincome country markets themselves.

Cuba provides a particularly fascinating case to consider, as it is a country that has been excluded from many aspects of neo-liberal global economic integration, yet over the past decade has experienced a dramatic growth in its tourism sector [42], [43], [44]. Potential impacts on communities from the expansion of tourism can thus be examined in a climate where global contacts have been relatively restricted - but in a context where policy options associated with this country's greater national independence are broader than other locales experiencing similar pressures.

\section{Tourism as an expression of globalization}

Over the course of the post-1970 period that is identified with the modern era of globalization, there has been a dramatic expansion of tourism - to the point where this sector is today considered by many to be the world's biggest business [45], [3]. As trends in transportation and information technologies have strengthened connectivity at the same time that global disparities have grown, an international market hungry for destinations has been drawn to economically marginalized locales that have provided unique travel opportunities. For the communities affected by this expansion, this has brought fundamental changes to their way of life [3].

Cohen [46] describes modern tourism as a complex ecological, economic, political and global system. He explains that the tourism system hinges on a group of national and transnational corporate actors and governmental and intergovernmental agencies, such as airlines; travel companies, travel agencies, and tour operators; hotel chains; international travel organizations; and various governmental and intergovernmental agencies operating in the context of international agreements that facilitate and regulate these interchanges. The global structure of the tourist industry, however, has important repercussions at the national and local levels in host countries.

Tourism, which has grown significantly since the late 80 s, presently generates more than $\$ 4.4$ trillion USD per annum - over $10 \%$ of the world's gross domestic product. It brings together people from different parts of the globe on a massive scale and has significant impacts on political, cultural, social, economic and environmental conditions of the communities in which it is developed- all factors that in turn have an impact on health. In lower and middle-income countries, tourism is often the main source of foreign currency [41], [47], [48] and is promoted as a way for developing nations dependent on primary resources to diversify their economies and finance valuable infrastructure. This is certainly true with respect to national economic development policies in Central America and the Caribbean [49], [50], [51]. 
In the Caribbean region, tourism has been the mainstay of the economy since the 1950s and the growth of this sector has been inextricably linked with the processes of globalization and the spread of neo-liberal policies [52], [53]. It has been well documented that these policies and processes - including the processes of tourism development - instigate structural and societal change with impacts at all levels from the individual to the community and beyond.

\section{Impact on host communities and populations}

There is an emerging literature on the socioeconomic and socio-cultural impacts of tourism on the host community or society. The distribution of benefits and costs associated with global tourism can be highly inequitable. Documentation assembled by the United Nations Environment Program [54], indicates that amid economic growth, tourism can bring loss of local identity and values, economic migration of people, cultural clashes, economic inequality, job level friction, crime generation, child labor, prostitution and sex tourism. On the other hand, higher earning jobs often go to foreigners while local people take on lower-paid jobs such as housekeepers, waiters, gardeners and other practical work in strongly genderdifferentiated roles.

While tourism can boost hard currency receipts, heavy infrastructure investment eats up resources that could be used elsewhere and often replaces one 'single-crop' economy for another [41], [46], [47], [3]. Moreover, the benefits of tourism are far from evenly distributed. Tourism may furthermore lead to increased social, class and gender differentiation. Employment created in the community tends to be predominantly in low status, low paid and temporary jobs - especially in cases where primary production activity is displaced. Studies increasingly indicate that position within a social hierarchy is important for health, and that the gradient that appears across the social spectrum exists for all-cause mortality as well as a wide range of diseases, especially coronary heart disease, diabetes, gastrointestinal disease, respiratory diseases, arthritis, adverse birth outcomes, as well as for accidents and violent deaths [55], [56].

In relating this to the phenomenon of globalization and tourism development, increased interaction with affluent global tourists can contribute to the perception of disparity (both real and imagined) between the host culture and tourists. This interaction also strongly contributes to a demonstration effect, where locals (who are in a more dependent and less powerful position) begin to copy or mimic the behaviors, attitudes and appearance of visitors. The following observation brings this concept to life: "Everyone is on his own. Imitating the lifestyle of the holidayers whom he or she serves. More and more tourism alienates. The desire for another life/life-style thus can promote consumerism, discontent, as well as the potential break-up of community and family as younger generations turn away from tradition [52].

Therefore, while tourism sector expansion can generate impacts on local ecologies just as any other investment project can disrupt existing patterns of land use, there is a particular need to consider the psycho-social impacts of this "social interaction-intensive" sector. The sociocultural impacts of tourism in host communities have been measured in different ways [5], [20], [32]. For example, the parameters for monitoring sociocultural impacts proposed by Pitamber Sharma [57].

In many ways, coastal communities are especially vulnerable to the pressures of globalization and can serve as sentinels. The spatial, natural resource and ecological characteristics that have shaped the development of such areas historically (e.g. fishing, forestry) make them 
differentially subject to global changes (e.g. the primary resources exploitation previously favored can be threatened by ecological changes and global competition; while their "aesthetic settings" become global commodities as transportation technologies have evolved to support increases in people flows).

Tourism is therefore an excellent sector upon which to focus in exploring the community-level effects of globalization as well as the mitigation of deleterious impacts. The risk of negative impacts outlined above must be considered against the potential benefits that can accrue from a generation of wealth and income associated with tourism, the factors often exclusively stressed by tourism's proponents. Thus, equal attention must be devoted to consideration of how to mitigate negative impacts and capture benefits for local populations who may otherwise be affected.

\section{Special case of Cuba}

\section{RESULTS AND DISCUSSION}

Cuba provides a relatively unique opportunity for studying the phenomenon of tourism development, especially with regard to psychosocial factors. Despite its isolation from the mainstream of the global economy, Cuba has achieved and maintained an exceptionally high level of population health. This achievement "on the margins of globalization" suggests that greater equity-oriented policy independence unfettered by neo-liberal pressures can in fact produce positive health results [58]. Cuba's excellent health outcomes can be traced to a comprehensive set of policies that have ensured access to basic determinants of health as well as the establishment of a comprehensive primary health care system that has been universally accessible.

While the provision of social services has been under strong attack in neo-liberal development patterns, Cuba has maintained a strong commitment to this. For example, in Cuba, all education is public. There is no tuition or fees, even at the university level, and the government provides schoolbooks at no charge. Virtually all housing and related costs, water, electricity and telephone in Cuba are highly subsidized by the government. These policies have had a largely equalizing effect across the country. Following the revolution and prior to the Special Period (the period of economic decline accompanying the collapse of the Soviet Union and Eastern bloc, Cuba's main trading partners in the late 1980s and early 1990s), Cuba had a policy aimed at full employment. While such policy persists, it has been difficult to sustain because of the profound changes brought on by the Special Period and a more "globalized" economy.

However, with the reintroduction of tourism and the legalization of the use of the US dollar, much needed to obtain foreign exchange, Cuba's social achievements were increasingly being subject to new threats. From a circumstance where "poverty was shared relatively equally", tourism not only entailed a highlighting of disparities between Cuban citizens and foreign tourists, it created conditions of unequal access to financial resources (i.e. US dollars) among Cubans themselves [56], [59]. The retention of broad policy options to deal with these pressures, typically surrendered by countries immersed in a neo-liberal development model, however, provides another dimension for considering how such pressures can be resisted and mitigated, to capture benefits while limiting negative effects.

\section{Tourism in Cuba}

Tourism was an important sector of the Cuban economy prior to the revolution in 1959, and was closely linked to gambling, prostitution and corruption. As the country set out on a more broadly based economic development course, with the benefit of assistance from the Soviet 
Union and the Eastern bloc, the number of visitors to the country dropped dramatically from 272,300 in 1957 to 87,000 in 1960 [60]. This turning away from international tourism was further entrenched by the embargo imposed by Cuba's neighbor and natural market, the United States that prevented U.S. citizens from traveling legally to Cuba. Thus, the broad range of tourism-related activities - restaurants, casinos, luxury resorts, marinas and a range of entertainment facilities - were rapidly dissolved. Over and above this, until the late eighties and start of the 1990s, in the context of a protectionist relationship with the Soviet Socialist bloc, Cuba prospered and remained relatively quite isolated from the broader impacts of globalization.

With the sudden collapse of its trading partners who had accounted for over $85 \%$ of exports, Cuba was suddenly and forcefully pushed into the global realm, especially seeking ways to earn foreign exchange. It has been well documented in the former Soviet Union that dramatic structural change, characterized by social disruption and economic hardship can have pronounced negative physical and mental health impacts on individuals [61]. In terms of Cuba's financial recovery, however, tourism development was specifically identified as the key sector for growth. Thus, while Cuba managed to avoid the broad-based adoption of the neoliberal policies that dominate other Caribbean and Latin American nations, reintegration into global tourism expansion nonetheless simultaneously has provided the basis for exposing local communities to a broad range of international pressures, amid the growth of economic activity. Tourism is now Cuba's number one national area of economic activity and, as such, the government has developed two explicit tourism objectives: to systematically increase revenue generated by the industry and to increase the number of tourist arrivals from each year. Investment into this sector has increased substantially with construction of new hotels and accompanying infrastructure. Unlike other Caribbean nations, however, the socialist framework of the Cuban economy stipulates that all firms be either wholly-owned by the government or majority-owned joint ventures with international companies. Central to this is the degree to which people participate in an "informal" economy alongside the expansion of tourism, which these critics suggest lays the basis for "corruption, widespread theft, marginality and the black market, mass exodus, and jinetero [i.e. hustling] as survival strategies.

Concurrent with the targeting of tourism for expansion, in 1993, the US dollar became the officially accepted currency for the tourism sector on the island. While this policy undeniably further facilitated economic activity and earning of foreign exchange alongside the capture of remittances from Cuban families receiving these from abroad (mostly the U.S.), it simultaneously also introduced a serious threat to equity and related values associated with years of Revolutionary policy [62]. For example, those with access to US dollars, especially from formally or informally working in the tourism sector, had significantly more buying power than those only earning income in national currency [42].

Although Cubans receive some benefits of subsidized necessities such as food and housing, increasingly necessary goods, such as clothing, typically required dollars. This particular discrepancy accordingly introduced the potential of an "efforts-reward imbalance", an imbalance that is believed to critically increase risk of ill health such as depression, anxiety, and chronic fatigue [63]. Free circulation of the U.S. dollar as a principle currency in tourism continued as national policy until November 2004, when the Cuban government declared that 
this currency would no longer be accepted, due to a host of reasons related to the retention of sovereignty and control of such matters.

In the period from January to December 2015, a total of 3,524,779 of visitors were received; 3 490710 tourists and 34069 hikers, this final included 9922 cruise passengers [43]. The main emitting countries have been Canada, Germany, Italy, France, England, Spain, Mexico, Venezuela, Argentina, China, and Russia [43]. With the expansion of tourism, then, factors such as access to opportunities to work in the formal tourism sector, involvement in the informal sector, and the gender differentiation of roles in this sector have introduced new dimensions to daily life. Women, for example may now assume a strategically critical role in earning income while maintaining household responsibilities, while men may find their role as "providers" disrupted from patterns that preceded this sector's expansion. These are the strains and opportunities faced by individuals and communities at a local level - and the contexts that local policy makers themselves confront in considering their options.

\section{Developing and applying a framework for policy response}

In the context of the potential population health implications of tourism expansion discussed above, the challenge that emerges, thus, is not merely to better identify the risks and threats that constitute pathways that can lead to local health effects (Table 1), but to consider options for mitigating negative impacts (the action column in this table) and taking advantage of positive opportunities, as is also illustrated by Figure 2 which presents the context in which these responses can be framed.

\section{Table 1 - Pathways for health impacts and responses associated with tourism expansion in Cuba}

\begin{tabular}{|c|c|c|c|c|}
\hline & GLOBAL & NATIONAL / COMMUNITY & ACTION & INDIVIDUAL \\
\hline $\begin{array}{l}\text { Driving } \\
\text { Force }\end{array}$ & $\begin{array}{l}\text { - Transportation \& communication } \\
\text { technologies facilitate travel } \\
\text { - Economic growth in High Income } \\
\text { Countries creates mass market } \\
\text { - Commodification of leisure } \\
\text { - U.S. embargo \& emigration incentive } \\
\text { - Collapse of Soviet Union and Eastern } \\
\text { Bloc trading partners }\end{array}$ & $\begin{array}{l}\text { - Economic decline in } 90 \mathrm{~s} \\
\text { - Need for foreign currency } \\
\text { - Need for employment } \\
\text { - Resistance to US embargo } \\
\text { - Political independence }\end{array}$ & 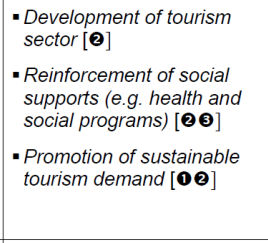 & $\begin{array}{l}\text { - Will to improve quality of life and maintain } \\
\text { dignity } \\
\text { - Families in U.S. / remittances / pressure to } \\
\text { emigrate } \\
\text { - Will to maintain families } \\
\text { - Survival in difficult economic } \\
\text { circumstances }\end{array}$ \\
\hline Pressure & $\begin{array}{l}\text {-\# of International tourists } \\
\text { - Development of tourism destinations } \\
\text { - "Demonstration effect" on adopting } \\
\text { lifestyles (esp. from U.S.) }\end{array}$ & $\begin{array}{l}\text { - Development / expansion of } \\
\text { sites \& access } \\
\text { - Increase in \# of tourists }\end{array}$ & $\begin{array}{l}\text { - Adoption of policies to } \\
\text { capture benefits \& mitigate } \\
\text { effects }[\mathbf{Q}] \\
\text { - Preparation of local } \\
\text { populations [0 }\end{array}$ & $\begin{array}{l}\text { - Limited economic alternatives } \\
\text { - Opportunities for direct involvement in } \\
\text { formal and informal tourism activities } \\
\text { - Changes in social and ecological } \\
\text { environments }\end{array}$ \\
\hline State & $\begin{array}{l}\text { - Tourism-related transactions } \\
\text { - Dollar flows } \\
\text { - Tastes and values conveyed } \\
\text { (materialism, individualism) }\end{array}$ & $\begin{array}{l}\text { - Tourism days and interactions } \\
\text { - Financial outlays } \\
\text { - Status of social cohesion } \\
\text { - Status of cultural cohesion }\end{array}$ & $\begin{array}{l}\text { - Development of new } \\
\text { infrastructure }[\mathbf{\theta \Theta}] \\
\text { - Distribution of benefits } \\
{[\mathbf{\theta \Theta}]} \\
\text { - Reinforce collective values } \\
{[\mathbf{\theta \Theta}]}\end{array}$ & $\begin{array}{l}\text { - Employment in formal \& informal tourism } \\
\text { sectors } \\
\text { - Social interactions with tourists } \\
\text { - Cultural life } \\
\text { - Gender roles }\end{array}$ \\
\hline Exposure & $\begin{array}{l}\text { - Interactions / isolation from local } \\
\text { populations }\end{array}$ & $\begin{array}{l}\text { - Interactions with tourism } \\
\text { expansion } \\
\circ \text { Personal } \\
\circ \text { Community }\end{array}$ &  & $\begin{array}{l}\text { - Direct interactions with tourists } \\
\text { - Risks from changes in behaviour (e.g. } \\
\text { alcoholism, drug etc.) } \\
\text { - Risks from impacts (being identified in } \\
\text { greater detail by pilot study) } \\
\text { - Reduced and increased risks associated } \\
\text { with increased income }\end{array}$ \\
\hline Effect & $\begin{array}{l}\text { - Distribution of costs and benefits } \\
\text { - Health of tourists } \\
\text { - Impacts of interaction }\end{array}$ & - Distribution of costs and benefits & $\begin{array}{l}\text { - Access to services (e.g. } \\
\text { health) }[\mathbf{0 4}]\end{array}$ & $\begin{array}{l}\text { - Effects associated with direct (e.g. } \\
\text { psychosocial) \& indirect effects (e.g. social } \\
\text { determinants) of change - details and } \\
\text { effectiveness of mitigating impacts being } \\
\text { developed in pilot study }\end{array}$ \\
\hline
\end{tabular}

The "driving forces" that have set the stage for an expansion for tourism can best be seen to have been generated from both within and outside Cuba. This, by itself, is not particularly distinct from other low and middle income countries, where economic benefits are explicitly identified in supporting expansion of this sector. Whether and how the increased revenues 
generated by tourism actually serve to improve the sustainability of providing basic population services, however, is a matter that can be empirically observed in terms of both process and outcome. Furthermore, whether and how identified pressures can be resisted through a strengthening of preparation and individual and community coping mechanisms is even more directly observable. The conceptual frameworks developed in this paper are intended precisely to provide the tools for use in such enquiry and preparation at the affected community level.

Figure 2 Logic Model of interactions linking Globalization, Tourism and Health

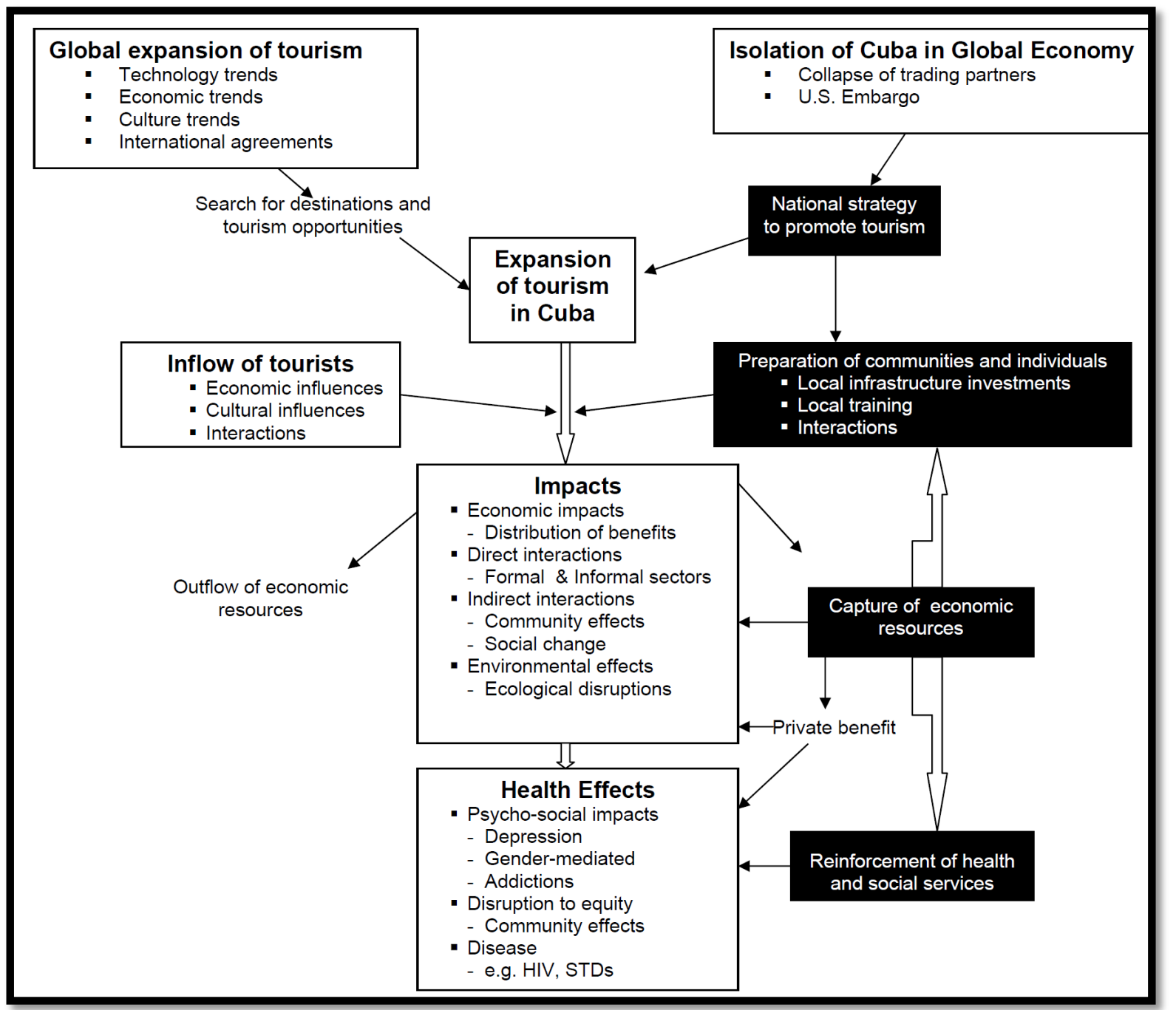

In this way, the preliminary observations noted in Table 1 and Figure 2 are precisely the subject for further investigation among stakeholders as well as the participatory development of a plan for ongoing monitoring and evaluation (Table 1, Figure 2). Whether the state capacity for contributing to a policy and action response to identified pressures can be observed, and the actual health impacts in relation to this can be measured. Using appropriate study designs, an evidence base for policy responses to the pressures of globalization can thus be built. The pilot study we are undertaking to apply this model will examine how a community is anticipating and preparing for the development of a new tourism expansion, while comparing this to and learning from an earlier development that did not incorporate the same degree of planning and hence was left to develop a more reactive orientation to tourism development. 


\section{Case of study: Cárdenas and Caibarién}

For the development of this study, two coastal communities have been selected, Cárdenas and Caibarién. Here are the most important characteristics identified.

\section{Cárdenas}

The municipality of Cárdenas has an area of $564.89 \mathrm{~km}^{2}$ which represents $14.8 \%$ of the Matanzas province, and $0.5 \%$ of the area of Cuba. The area is defined to the north by the width of Florida and the municipality of Varadero. To the south, east and west, Cárdenas is bordered by Jovellanos, Limonar, Martí and Matanzas municipalities. Cárdenas has a particularly advantageous geographical location because of its proximity to Varadero and Havana, the two most important locations for tourism in the country. This has significantly influenced the city's municipal development and on social and economic levels. Cárdenas has around 100,000 residents and a population density of 169 people per square kilometer. Eighty-one percent of the territory's population lives in the city itself.

The manufacturing, service and tourism industries constitute the fundamental economic activities that have been developed in the territory. The main extractive businesses in the area are the Drilling Company and the Petroleum Centre, which produce more than half of the total petroleum extraction in the country and about $70 \%$ of the natural gas production. The environmental condition in Cárdenas is marked by various environmental problems which may or may not be linked to tourism development in Varadero. According to the Municipal Environmental Strategy (CITMA, 2005), the municipality's environmental problems are: contamination of ground and sea water, deterioration of sanitary hygiene conditions, lack of education, decreased environmental consciousness, deforestation, soil degradation, and loss of biodiversity.

\section{Caibarién}

The municipality of Caibarién has an area of $212.2 \mathrm{~km}^{2}$. It is located to the northeast of Villa Clara province, a location that has facilitated its economic and social development. It contains the coastal zone and an insular area where the small cays Las Brujas, Ensenacho and Santa María are known for their spectacular natural beauty. The cays have been attached to the mainland since 1994 by approximately $48 \mathrm{~km}$ of highway built above the sea. The highway, or Pedraplén, unites the insular zone, which was recently developed for tourism, with the coastal city of Caibarién.

Caibarién has a population of 40,798, of which 20,118 are male and 20,690 are female. The population density is 148.89 people per square kilometer. Most of this population, 92 percent or 37,555 people, live in urban settlements. The population is predominantly adult and has a low growth rate and negative immigration rate. The structure of the local political administration is based on 07 popular councils, 03 of which are urban, 01 is suburban and 03 are rural.

Caibarién has experienced important structural transformations in its traditional economy throughout history, which has been the cause of various social impacts. The port development failed in 1930 and the sugar industry ended in 2002 when the "Marcelo Salado" plant closed down under the new national development strategies. The plant was subsequently converted into the Agro-industry Museum while residents were forced to develop other economic activities. Nevertheless, the primary economic sector in the urban setting remained linked to the fishing and the service industries. Then, in the early 1990s, the city reopened to international tourism. Tourism proceeded to become an important local economic activity. It 
now takes place in the glorious beaches along the coastal cays, more than $50 \mathrm{~km}$ from Caibarién.

Caibarién's geographical location positions it as the primary source of labor for the tourism industry. Caibarién's cultural component complements the beach aspect of tourism in the region. It is expected that because of this additional attraction the interaction between tourists and hosts will increase. Caibarién is integrated as a tourist sub-region within the Villa Clara tourist area. It includes three beach resorts, Santa María Cay, Ensenachos Cay, and Las Brujas Cay, and one urban site (the city).

The resorts and the urban area complement each other and form a tourist attraction that has more than just the beach component. Currently, Caibarién does not have the capacity to lodge national and international tourists. The actual accommodation infrastructure consists of one hotel, five private hostels and rustic tourist villas, as well as some guesthouses. In comparison, the coastal cays offer an ample and very comfortable infrastructure with enormous potential for hotel development.

\section{SUMMARY OF THE RESULTS OF THE FOCUS GROUPS}

Results obtained primarily from focus groups in Cárdenas and Caibarién, and enriched by other sources according to the methodology, provide a broad view of perceived impacts of tourism.

\section{Economic impacts}

Most participants in the focus groups recognized the importance of tourism for its national and local economy. The following are some of the major issues that were identified from the discussions in the focus groups:

- Tourism has been used as an economic strategy in order to increase the overall economic level of the country. Tourism appears to have a multiplier effect.

- As a consequence, more jobs are created locally in different manufacturing and service sectors, especially for youth and women; less unemployment

- Workers have higher wages and salaries.

- Higher family income, especially for those in the tourism industry

- Tourism contributes to the development of social and economic programs in the country and the Municipality; the health and educational sectors have been sustained and even strengthened with the revenues from tourism.

- It represents the largest source of revenue for the country.

- More housing and better infrastructure in the community

Although it was acknowledged that tourism contributes to the development of other economic sectors, a negative impact on the economy was identified as the disappearance of the fishing industry typical of coastal communities.

\section{Impacts on labor}

- Work force is shifting from the health and education sectors to the tourism sector (Cárdenas)

- More job opportunities for youth

- Better working conditions in tourism sector

- Less protection by union regulations 
- Competing work force coming from other areas

- Long work hours

- A lot of pressure from work (in tourism); important to keep the job to support the family

- Husband and wife may have different shifts

\section{Cultural impacts}

Impacts on culture have been seen largely as positive if changing diet and fashion is not considered in this dimension. Comments about tourism can be grouped as follows:

- It provides the awareness to raise the cultural level of the community in areas such as languages, history and local and national traditions.

- It is a way of creating incentives to preserve and improve the cultural heritage as well as to promote the local culture and traditions.

\section{Educational impacts}

- People achieve a higher educational and professional level through special courses that provide them with higher training in areas of tourism services.

- On the other hand, many university professionals seek jobs in the tourist sector, "even washing dishes", in order to make more money.

- Fewer students going to high school (Cárdenas)

\section{Social impacts}

Social impacts of tourism on the community were perhaps the most widely discussed by participants in the focus groups.

\section{Positive}

- Tourism contributes to a higher standard of living in general for the community.

- The community is more stable and permanent now in Caibarién; there is a beginning of a process of attraction of population from other areas to this Municipality

- Better housing - although mostly for tourism workers

\section{Negative}

- Increased prostitution - and increased STDs - as well as more drug consumption in Cárdenas; this is not perceived as a problem in Caibarién

- Increased corruption and illegal activities (Cárdenas)

- Deterioration of social values

- Increased immigration towards Cárdenas - some illegal

- Increased social disparity among Cubans - particularly negative for young people

- Workers in the tourism sector earn more and have increased consumption and access to more goods; they also have preferential treatment as better and assured transportation

- Barriers to get to tourist areas [this is also considered a mitigating factors that regulates the relationship between tourists and Cubans in hotels in order to prevent spread of STDs]

- Community lifestyle changes; someone said: "Everything changes." Eating/diet habits, dressing fashion, friendships have broken

- Exposure to other cultures produces a change in behavior and taste

- Work in tourism is the main goal of youth 


\section{Impact on women}

- It has generated more employment for women and more women work in the tourism sector; this has created problems where men used to be the main provider (Caibarién)

- Increased prostitution; some people entice the tourists to seek women (Cárdenas); no prostitution in Caibarién

- Physical work is heavier for women

\section{Impact on family}

- Less time for the family; parents working in the tourism sector provide less care to their children

- Husband and wife may have different shifts; this prevents them from spending time together (Cárdenas)

- Some families have split

- More separations and divorces

\section{Inter sectorial and social cohesion}

- Lack of coordination between tourism sector and other sectors (decision-makers in Caibarién)

- No links between some municipal activities and tourism activities (decision-makers in Caibarién)

- All sectors of the community are involved (community group in Caibarién)

- Need to work with the police to ensure safety of tourists (Cárdenas)

- Stronger social cohesion: "there are no outcasts; they all look for the community wellbeing." (Caibarién)

- Tourism worker has less contact with larger society

\section{Political impacts}

- As a driving force tourism has been recognized by decision makers and community members of Caibarién as a challenge to the ideology.

- "People need to be vigilant" particularly in relation to youth.

- Tourism is a way to show Cuban society and what we do.

\section{Environmental impacts}

- Increased awareness about care of the environment; garbage is not dumped everywhere - some areas give a poor impression to tourists

- There is a larger volume of solid waste; as a result, Cárdenas has a new solid waste processing plant.

\section{Health impacts}

\section{Community}

- More garbage bins and garbage trucks; more frequent garbage collection; more control of vectors

- Broader view of health that includes a healthy environment

- "People are more aware about health."

- Better sanitation but water supply still a problem (Cárdenas)

- Workers in tourism have vaccine shots and other tests as prevention

- Tourism workers have some more privileges than health workers 
- Fear of importing exotic diseases already eradicated in Cuba (cholera, vector-borne)

\section{Physical}

- Higher prevalence of hypertension, pelvic problems and exposure to disinfectants and cleaners among tourism workers

- Obesity, cerebral-vascular diseases, heart attacks, arthritis, high cholesterol level

- Physical work is heavier for women - long hours standing: more propensity to back problems, pelvic problems and varicose veins

- Danger of sexually transmitted diseases (STD); $60 \%$ of HIV+ cases are related to tourism

- More concern about keeping in shape, getting massages, green medicine, better diet, reduction in smoking

\section{Psychosocial}

- "Tourism has a psychological impact on people."

- "Psychological impact is manifest in the difficulty to satisfy material needs for those who do not work in the tourist sector."

- Work related stress

- Alcoholism

- Drug use; addictions (Cárdenas - no problem in Caibarién)

- Some families have become dysfunctional

\section{Mitigating policies}

A series of policies or strategies have been mentioned by all focus groups that have been implemented in order to mitigate the negative impacts of tourism on the community. Some by area of concern are:

\section{Health}

- Community committees with a large representation have been developed for the prevention and control of HIV and STDs; extensive use of media

- Continued diagnostic about drug use and addiction

- Early warning system to detect exotic diseases

- Epidemiological surveillance for vectors

- A program to discuss environmental health: "My nice home \& my healthy home" (Caibarién)

- Strategies at the municipal level for the protection of the environment and the coast specifically

- Regulation of the relationship between tourists and Cubans in hotels in order to prevent spread of STDs

- Deployment of physicians in all tourist hotels

- Deployment of social workers for general problems (Caibarién)

\section{Community}

- Policy to control illegal immigration into the municipality of Cárdenas

- Vocational orientation for children and youth to guide them to enter professions that are needed in the country

- University involvement in development and research projects for the municipality

- Weekly "System meetings" with health professionals community and political leader (Caibarién) 
- Continued effort in ideological work from the grass roots level to stop the impact of tourism on youth and the community; neighborhood meetings called "Barrio debate" (Neighborhood debates) (Caibarién)

- Community programs: "Jardines del Rey", "Adolescencia Feliz" and others for seniors and housing (Caibarién)

- Workshops with workers to discuss job and social concerns (Caibarién)

\section{Evidences of the field}

This pilot study proposes a practical methodology for a rapid community-based assessment of the impact of tourism on coastal communities. Focus groups appear to be an accurate initial gauge of the process of tourism development and the broad coverage of the focus groups to include all community stakeholders is a key element. Overall, the interventions of participants were active and informed and addressed the areas of interest. The analysis of the information appears to imply issues related to globalization as a driving force for tourism development and its impacts. The assumption that globalization brings pressure to adopting a certain ideology, seems to have been identified in the statement "tourism brings changes to the ideology."

Other issues linked to globalization were:

- Tourism is good for the economy, but it appears to have disruptive impacts as displacing traditional sectors (fishery) and displacing people and work force.

- Socially it has created disparities.

- On the positive side, local culture can be projected to other countries; but this puts pressure on the local community to develop a cultural and social infrastructure that presents the best.

- Tourism brings changing lifestyles: "everything changes".

The link between tourism and local communities has been highlighted in terms of impacts on physical and mental health. The impact of tourism on gender is very evident for the local communities. While there are more jobs available to women, the emphasis on the increased prostitution shows a strong negative impact on women. A comment was made about affecting the family dynamics with changing roles as 'main provider' in the family. Other impacts on the family will likely affect women as well.

The focus groups discussions in Cárdenas and Caibarién also reflect the different stages of tourism development in the two communities. In general, Caibarién seems to be better prepared for the impacts of tourism as indicated by the more specific programs and policies aimed at mitigating the negative impacts. Early results of this preparedness may be inferred by the statement "In Caibarién it is not like in other municipalities ... like Varadero [Cárdenas] [and] Havana where there have been more tourists and more negative impacts." In fact, prostitution and drug addiction have not been identified as current problems as in Cárdenas. There is a similar relation between the shift in the work force toward tourism and uncontrolled immigration in the community.

Caibarién might be in the early stage of 'relationship' with tourists as suggested by statements such as "tourists learn more about Cuba while interacting with Cubans", and "it allows us to promote our culture in the world." A full verification of the methodology may only occur with an analysis of the indicators or measures of the suggested impacts. Nevertheless, the methodology proposed in this pilot study appears to validate some of the assumptions about 
the pathways between globalization, tourism and impacts. Negative impacts are inevitable and only early proactive policies may provide the prevention of those impacts.

These negative impacts are inevitable because they have already been felt by the local community, who has perceived them in this way. Therefore, it is necessary to reconsider the preventive management of impacts related to policies and control strategies needed to eliminate, mitigate, compensate, and develop resistance / adaptation capacities, as well as monitor and create surveillance systems on the effects perceived by the community.

\section{CONCLUSION}

In an increasingly globalized world, the challenges being faced by communities that face restructuring are universal, albeit subject to their own local circumstances. Examining case study experiences through the involvement of collaborative multi-national teams provides an opportunity to consider elements that may contribute to global understanding of pressures and policy options. While Cuba is in many ways unique, especially in the policy independence it pursues in responding to the pressures of globalization, we feel that the approach described above can provide valuable lessons to the international community in navigating a course between the allure of tourism dollars and the health and well-being of local populations. It is planned that the in depth findings of the pilot study, to be published when all community based field work is complete, will be used to monitor how well benefits are captures and negative impacts mitigated. We also hope to use the framework being developed to serve as a basis for comparative cross-country and cross-sector studies.

According to the opinions and behaviors of the participants in the focus groups developed in Cárdenas and Caibarién it is recognized that the expansion of tourism on coastal communities directly and/or indirectly affects them. It is an important point to project alternatives for development based on the perception of the tourism model implemented at the local destination, allowing the possibility to improve the relationship between tourism and the host community.

The pilot study concluded that the local community is able to identify the links between tourism development and its impacts. They can explain pathways that link the impact of tourism, and the policies that influence them. In addition, direct and indirect effects on the local communities across their lifespan are perceived, with emphasis on the evolution of impacts on social organization.

Field research conducted in Cuba also demonstrates that tourism impacts vary at different stages of tourism development. The know-how developed in Cárdenas regarding the traditional model of tourism could be an appropriate way of promoting an alternative model of tourism development based on sustainable principles. Due to the different stages of development both cities are in, it is perfect timing to promote a preventive plan for controlling negative impacts of tourism perceived by the community in Caibarién.

Comprehensive qualitative and quantitative indicators were identified by the focus groups in Cárdenas and Caibarién. These might be indicative of the 'real' impact of tourism and could be used to develop future research projects. Both men and women felt adequately represented by the indicators, and showed consensus on indicators and research / measurement protocols based on their own experiences. 
Mitigating policy measures to protect and promote tourism development were recognized by the local community. It is possible to develop preliminary consensus on the policy implications and policy options among policy-makers, researchers and community leaders. They are able to identify a series of strategies and actions in order to mitigate the negative impacts of tourism on the community according to different areas of concern.

As a research learning experience this study provides a methodology to identify how tourism affects social organization in communities, in order to consider different policy implications and management options. At the same time it offers empirical evidences based on a case study for those interested in rapid assessment of tourism impacts through community participation. The value of the results is related to the projection of new strategies of management for the future development of tourism in both communities; Cárdenas which is located near a mature destination like Varadero, and Caibarién which associated with the new destination of "Cayos de Villa Clara". The next stage could be a proposal of a preventive plan for impacts management; it should be designed according to the community perceptions of the impacts of tourism, and the policies that influence them.

The findings could be applied to a wider global community in Cuba. It is recommended to improve the methodological approach developed with the participation of the community applying a Rapid Assessment Technique. This brings together the local communities' residents with policy-makers, researchers and community leaders; generating space for understanding, learning, and engagement of all social and economics agents.

\section{References}

Trivelli, Pablo. 2010. The sustainability of urban heritage preservation: interventions to support economic and residential investments in urban heritage areas of Latin America and the Caribbean (rg-t1620).

Leigh, James; Craig Webster; and Stanislav Ivanov. 2012. Future Tourism. Political, Social and Economic Challenges. Routledge. Taylor \& Francis Group Ltd.

Organización Mundial del Turismo /OMT/. 2013. El turismo como inductor del desarrollo, de la inclusión social y de la integración regional. PDF. Parte I y II. 142 pp. http://www.e-unwto.org/ [recuperado el 19 de julio de 2015].

Comisión Económica para América Latina y el Caribe de las Naciones Unidas /CEPAL/. 2011. Ingresos por turismo representan más de 30\% del PIB para algunos países de la región. 21 de marzo de 2011 | Comunicado de prensa. http://www.cepal.org/es/comunicados/ingresos-por-turismo-representan-mas-de-30-del-pib-para-algunospaises-de-la-region [recuperado el 19 de julio de 2015].

Ateljevic Irena; Nigel Morgan; y Annette Pritchard. 2011. The Critical Turn in Tourism Studies. Creating an Academy of Hope. Routledge. Taylor \& Francis Group Ltd.

Harris, Peter. 2011. Profit Planning for Hospitality and Tourism. $3^{\text {rd }}$ Ed. Goodfellow Publishers Ltd, Oxford.

Ivars i Baidal Josep A; Isabel Rodríguez Sánchez; and José Fernando Vera Rebollo. 2013. The evolution of mass tourism destinations: new approaches beyond deterministic models in Benidorm (Spain). Tourism Management 34 (2013) 184e195. Disponible en: www.elsevier.com/locate/tourman [2013, 10 de junio].

Ritchie, J. R. B. y Crouch, G. I. 2003. The competitive destination: A sustainable tourism perspective, Wallingford, UK, CABI Publishing.

Gössling Stefan; C. Michael Hall; and David Weaver. 2012. Sustainable Tourism Futures. Perspectives on Systems, Restructuring and Innovations. Routledge. Taylor \& Francis Group Ltd.

Legrand, Willy; Claudia Simons-Kaufmann; and Philip Sloan. 2012. Sustainable Hospitality and Tourism as Motors for Development. Case Studies from Developing Regions of the World. Routledge. Taylor \& Francis Group Ltd. 
López de Ávila Muñoz, Antonio y Susana García Sánchez. 2015. Destinos Turísticos Inteligentes. http://www.minetur.gob.es/Publicaciones/Publicacionesperiodicas/EconomiaIndustrial/RevistaEconomiaIndust rial/395/LOPEZ\%20DE\%20AVILA\%20y\%20GARCIA.pdf [recuperado el 19 de julio de 2015].

Huynen MMTE, Martens P, Hilderink HBM. 2005. The health impacts of globalization: a conceptual framework. Globalization and Health 2005, 1:14.

Fernández Tabales, A. 2002. La gestión local del desarrollo turístico: competitividad, sostenibilidad y participación social. En: Turismo y Sostenibilidad. Un acercamiento multidisciplinario por el análisis del movimiento y de las estrategias de planificación territorial. Brigati Genova. Italia. Page: 111- 122.

Lankford, Samuel V; Jill Lankford; Oksana Grybovych; and Richard Harding. 2013. Introduction to Tourism A Community-Based Approach. Sagamore Publishing LLC.

Global Health Research Program. 2004. Conference on Globalization Social Organization and Health. University of British Columbia. April 21-23, 2004. [http://www.cgh.ligi.ubc.ca/April\%2004\%20Conference/index.htm] [recuperado el 19 de julio de 2015].

OECD. 1997. Societal cohesion and the globalizing economy. Paris, Organization for Economic Cooperation and Development.

Cameron D, Stein J. 200. Globalization, culture and society: the state and place amidst shifting spaces. Canadian Public Policy 2000, 2: 15-34.

Ávila, R y Barrado, D. 2005. Nuevas Tendencias en el Desarrollo de Destinos Turísticos: Marcos Conceptuales y Operativos para su Planificación y Gestión. Cuaderno de Turismo, №15. España.

Mason, Peter. 2008. Tourism Impacts, Planning and Management. $2^{\text {nd }}$ Edition. Routledge. Taylor \& Francis Group Ltd.

Edgell, David L. and Jason Swanson. 2013. Tourism Policy and Planning Yesterday, Today, and Tomorrow. $2^{\text {nd }}$ Edition. Routledge. Taylor \& Francis Group Ltd.

Cabrini, Luigi. 2014. Tendencias del turismo sostenible y el rol del Consejo Global (GSTC). Presidente de la Junta Directiva del Consejo Global de Turismo Sostenible (GSTC) y Consejero del Secretario General, Organización Mundial del Turismo (OMT). Primer Congreso de Eficiencia Energética y Sostenibilidad en el Sector Turístico. Palma de Mallorca, España. http://docplayer.es/2312294-Tendencias-del-turismo-sostenible-y-el-rol-delconsejo-global-gstc.html [Recuperado el 02 de junio de 2016].

Dollar D. 2001. Is globalization good for your health? WHO 2001, 79: 827-833.

Labonte R. 1998. Healthy public policy and the World Trade Organization: a proposal for an international health presence in future world trade/investment talks. Health Promotion International 1998, 13: 245-56.

Cornia G. 2001. Globalization and health: results and options. Bulletin of the World Health Organization 2001, 79 : 834-841.

Kawachi I, Kennedy BP, Lochner K, Prothrow-Stith D. 1997. Social capital, income inequality and mortality. American Journal of Public Health 1997, 87: 1491-1498.

Veenstra G. 2002. Social capital and health (plus wealth, income inequality and regional health governance). Social Science \& Medicine 2002, 54: 849-868.

WHO-CSDOH. 2005. World Health Organization Commission on Social Determinants and Health. [http://www.who.int/social_determinants/knowledge_networks/globalization/en/index.html] Washington, D.C., WHO.

Woodward D, Drager N, Beaglehole R, Lipson D. 2001. Globalization and health: a framework for analysis and action. Bulletin of the World Health Organization 2001, 79: 875-881.

Labonte R, Torgerson R. Interrogating globalization, health and development. 2005. Towards a comprehensive framework for research, policy and political action. Critical Public Health 2005, 15: 157-179.

Hall Dereck; and Greg Richards. 2003. Tourism and Sustainable Community Development. Routledge. Taylor \& Francis Group Ltd.

Maldonado, Carlos. 2005. Pautas metodológicas para el análisis de experiencias de turismo comunitario. Copyright 8 Organización Internacional del Trabajo. Impreso en Ginebra, Suiza. 
Tsung, Hung Lee. 2013. Influence analysis of community resident support for sustainable tourism Development. Tourism Management 34 (2013) 37e46. Disponible en: www.elsevier.com/locate/tourman [2013, 10 de junio].

Spiegel JM, Labonte R, Ostry A. 2004. Understanding "globalization" as a determinant of health determinants: a critical perspective. International Journal of Occupational and Environmental Health 2004, 10: 360-367.

Spiegel J, Andruske CL. 2005. Globalization, health and the engendering of resistance in everyday life. In Globalization, Women and Health in the 21st Century Edited by: I Kickbusch, K Hartwig, J List. Hampshire UK, Palgrave Macmillan.

Appadurai, A. 1996. Disjuncture and difference in the global culture economy. In Modernity at Large: Cultural Dimensions of Globalization. Minneapolis, University of Minnesota Press.

Fraser N. 1989. Unruly practices: Power, discourse and gender in contemporary social theory. Minneapolis, MN, University of Minnesota Press.

Chin CBN, Mittelman JH. 1997. Conceptualizing resistance to globalization. New Political Economy 1997, 2: 25-37.

Briggs D. 1999. Environmental health indicators: frameworks and methodologies. Document WHO/SDE/OEH/99.10. Geneva, WHO.

Corvalán C, Briggs D, Kjellström T. 1996. Development of environmental health indicators. In Linkage Methods for Environment and Health Analysis. General guidelines. Edited by: D Briggs, C Corvalán, M. Nurminen. Document WHO/EHG/95.26. Geneva, WHO.

Spiegel JM, Bonet M, Yassi A, Tate B, Concepción M, Cañizares M. 2003. Evaluating the effectiveness of a multicomponent intervention to improve health in an inner-city Havana community. International Journal of Occupational and Environmental Health 2003, 9: 118-127.

Taylor M, Kealey L. 2004. Social and political restructuring and the health of individuals, families and communities. In The Impact of Social and Environmental Restructuring on Environmental and Human Health in Canada 2004 [http://www.coastsunderstress.ca/arm5/arm5.html] Victoria, Coasts Under Stress.

Martin de Holan P, Phillips N. 1997. Sun, sand and hard currency. Annals of Tourism Research 1997, 24: 777-795.

Peters P. 2002. International tourism: the new engine of the Cuban economy. Arlington, Lexington Institute.

Oficina Nacional de Estadísticas /ONE/. 2016. Turismo. Llegada de Visitantes Internacionales. Enero - diciembre de 2015. Edición enero 2016. http://www.one.cu/mensualllegadavisitantes.htm [consultado 24 de febrero 2016].

Gladstone P. 2001. Making the world safe for tourism. New Haven, Yale University Press.

Cohen E. 1984. The sociology of tourism: approaches, issues and findings. Annual Review of Anthropology 1984, 10: 373-392.

Weaver D. 1998. The less developed world. In Ecotourism in the Less Developed World. New York, Cab International.

Rodriguez-Garcia R. 2001. The health-development link: travel as a public health issue. Journal of Community Health 2001, 26: 93-112.

Freitag T. 1996. Tourism and the transformation of a Dominican coastal community. Urban Anthropology 1996, 25: 225-257.

Pi-Sunyer O, Thomas RB. 1997. Tourism, environmentalism, and cultural survival in Quintana Roo. In Life and Death Matters: Human Rights and the Environment at the End of the Millennium. Walnut Creek, Altamira Press.

Stonich S. 2000. The other side of paradise: tourism, conservation, and development in The Bay Islands. New York, Cognizant Communication Corporation.

Taylor F. 1993. To hell with paradise: a history of the Jamaican tourist industry. Pittsburgh, University of Pittsburgh Press.

Patullo P. 1996. Last resorts. London, Cassell.

United Nations Environment Programme. 2006. Environment for Development. [http://www.unep.org] Nairobi, UNEP.

Macintyre S. 1998. Social inequalities and health in the contemporary world: a comparative overview. In Human Biology and Social Inequality Edited by S Stickland, P Shetty. Cambridge, Cambridge University Press. 
Kristenson M, Eriksen HR, Sluiter JK, Starke D, Ursin H. 2004. Psychobiological mechanisms of socioeconomic differences in health. Social Science \& Medicine 2004, 58: 1511-1522.

Sharma P. CBMT. Parameters for assessing tourism impacts. 1998. In Community-Based Mountain Tourism conference 15 May 1998. http://www.mtnforum.org/emaildiscuss/cbmt/cbmt5/051598b.htm [recuperado el 19 de julio de 2015].

Spiegel JM, Yassi A. 2004. Lessons from the margins of globalization: Appreciating the Cuban health paradox. Journal of Public Health Policy 2004, 25: 96-121.

Robbins A. 1999. Havana Revisited. Public Health Reports 1999, 114: 183-185.

Quintana R, Figuerola M, Chirivella M, Figueras MA, García A. 2005. Efectos y Futuro del Turismo en la Economía Cubana. Havana, Instituto Nacional de Investigaciones Económicas. Cuba.

Hertzman C, Siddiqi A. 2000. Health and rapid economic change in the late twentieth century. Social Science \& Medicine 2000, 51: 809-819.

Blue SA. 2004. State policy, economic crisis, gender, and family ties: determinants of family remittances to Cuba. Economic Geography 2004, 80: 63-82.

Siegrist J. 1996. Adverse health effect of high-effort/low-reward conditions. Journal of Occupational Health Psychology 1996, 1: 27-41.

\section{ACKNOWLEDGEMENT}

The authors thank research study team members: GJ Cabrera; S. Catasus; M. Font; N. Pagliccia; and O. Diaz. Funding support from the Canadian Institutes of Health Research (CIHR) for the project reported in this article is gratefully acknowledged. Jerry Spiegel also acknowledges funding support from the Michael Smith Foundation for Health Research and the Institute for Population and Public Health (CIHR) 